\title{
Corrigendum to "feasibility of Using Metal Plate Connected Timber Strand LSL Joints in the Truss Fabrication Industry" [Bartın Orman Fakültesi Dergisi, 2016, 18 (1): 1 - 12]
}

Saadettin Murat ONAT ${ }^{1^{*}}$

${ }^{1}$ Bartın Üniversitesi, Orman Fakültesi, Orman Endüstri Mühendisliği Bölümü,74100, BARTIN

*The authors regret there was an error in author line related to a forgotten author and the corrected author Line is provided below.

Saadettin Murat ONAT ${ }^{1, *}$, Rafaat M. Hussein ${ }^{2}$

${ }^{1}$ Bartın Üniversitesi, Orman Fakültesi, Orman Endüstri Mühendisliği Bölümü, 74100, BARTIN

${ }^{2}$ SUNY, College of Environmental Science and Forestry, Syracuse, USA.

*There was an error in the letters in the Acknowledgements and the corrected author Line is provided below.

Acknowledgements

This paper is prepared from the Master's thesis submitted to SUNY-ESF, Syracuse USA in 1999.

These changes would not affect the results and conclusion of the whole manuscript. The authors would like to apologies for any inconvenience caused. 
